\title{
Impact of Technostress on Job Satisfaction: An Empirical Study among Indian Academician
}

\author{
R.K. Jena \\ Institute of Management Technology, Nagpur, 440013, India \\ E-mail: rkjena@imtnag.ac.in
}

\begin{abstract}
The contemporary world is becoming very stressful due to the fast changing Information and Communication Technology (ICT). Academic Institutions are also heavily depending on technology for teaching, learning and research. Therefore the pressures of ICT use in academics create technostress among academicians. Technostress can reduce employee satisfaction and create dissonance in the work environment. This study emphasized the impact of technostress on Job satisfaction among academicians in India. The study used Structural Equation Modeling (SEM) method to find the relationship between technostress creators and Job satisfaction. The findings showed a negative impact of technostress creators on job satisfaction.
\end{abstract}

Keywords: Job satisfaction, Technostress, Indian Academician, Technostress creators.

\section{Introduction}

Technology is becoming an integral part of every dimension of today's society. Technostress is a modern disease caused due to inability to cope with the new technologies in a healthy manner. These diseases manifest itself in the process to accept and adopt computer technology efficiently in work place. Those who struggle to accept computer technology often feel pressure to accept and use computers. On the other hand, technological advancement and revolution in organisation has not only improved efficiency and effectiveness but also helps reduce the problem of boredom and fatigue in the workplace ${ }^{1}$. The advancement of technology has also been a dominant force in improving and enhancing the teaching pedagogy in colleges and universities. In the same time, the rapid change of technology causes technostress among academicians in all types of educational institutions.

\subsection{Technostress}

The term technostress was first coined by clinical psychologist Dr. Craig ${ }^{2}$ in 1984 and defined as:

\begin{abstract}
"Technostress is a modern disease of adaptation caused by an inability to cope with the new computer technologies in a healthy manner. It manifests itself in two distinct but related ways: in the struggle to accept computer technology, and in the more specialized form of over identification with computer technology."
\end{abstract}

It is true that initially researchers looked at technostress as a disease. But, later researchers considered it more as an inability to adapt the changes brought by Information and Communication Technology (ICT). Davis-Milis ${ }^{3}$ found technostress as a pressure to adapt the new technology especially when there is inadequacy of the technology standard and training supports. But, according to Clark and Kalin ${ }^{4}$, the cause of technostress is the inefficiency to cope with the technological changes in the organization. They found that technology is not responsible for technostress, but technostress is a natural reaction to the technology. So, in order to manage and reduce technostress, each employee should be ready to adopt the new technology.

Technology has changed very fast since 1988, when the term technostress was first coined by Dr. Craig. ${ }^{2}$ 
The utilization of information and communication technologies (ICTs) in today's information driven society is very essential. There is no meaningful professional and economic growth and development can be possible without its utilization. Several benefits such as increased productivity, efficiency, accuracy, space economy and routine are derivable from the proper utilization of $\mathrm{ICT}^{5}$. On the other hand, technostress is becoming an un-avoiding part of technology use and many factors have been identified to define technostress more precisely. Tarafdar, RaguNathan, and Ragu-Nathan ${ }^{6}$ described technostress as a problem of adaptation due to a person's inability to cope with or to get used to the technology. They identified five components of technostress as follows:

- Techno-overload: A situation where technology (ICT) users are forced to work faster and longer.

- Techno-invasion: A situation where technology (ICT) users felt that they can be reached anytime or constantly "connected" which caused a blurring between work and personal contexts.

- Techno-complexity: A situation where technology (ICT) users feel that their skills are inadequate due to the complexity associated with the use of technology. As a consequence, they are forced to spend time and effort to learn and understand various aspects of technology.

- Techno-insecurity: A situation where technology (ICT) users feel threatened. They felt that they will lose their job either being replaced by the technology or by other people who are better in technology compared to them.

- Techno-uncertainty: A situation where technology (ICT) users feel uncertain and unsettled since technology is continuously changing with time.

\subsection{Job Satisfaction}

Job satisfaction is an emotional feeling of an employee about his/her job. Job satisfaction may be positive or negative. Irrespective of fields of knowledge, the construct job satisfaction has received substantial consideration of importance from researchers over last few decades due to its contributions toward employees' job performance and attainment of organizational goals ${ }^{7}$. In past, research findings were revealed that a satisfied employee is an effective job performer. Therefore, job satisfaction of academician can be one of the considerable dynamics in augmenting job performance and commitment. Job satisfaction is portrayed as an emotional attitude of person towards his/her job ${ }^{8,9}$. Job satisfaction plays an important role in enhancing organisational productivity. The major dimensions of job satisfaction are pay, promotion, supervision, job conditions, and benefits ${ }^{10,11}$. These dimensions are classified as; 1) intrinsic satisfaction; it signifies a category of situation or tasks that makeup the job, such as skills etc. and; 2) extrinsic satisfaction; it refers to work state of affairs, for instance pay, co-worker, etc. ${ }^{12}$

\section{Literature Review}

In $21^{\text {st }}$ Century, use of Information and Communication Technologies (ICTs) became a necessity in every individual's life. Early interactions with ICTs were mostly limited to the organization. But, with the advances in ICTs, the interactions now pervade organizational and personal spheres. These interactions force individuals to adjust with the use of ICTs ${ }^{13}$.These adjustments range from integration of ICTs into workplace, to the fear of becoming obsolete, to the phenomenon of technostress etc. ${ }^{13,14}$. Basically, technostress is the feeling of anxiety and it has the negative impact on thoughts, behaviors, attitudes, and body, when a person is expected to deal with technology ${ }^{15,16}$.

Universities all over the world are among the major organizations where ICT facilities are being used on a large scale to increase the productivity and knowledge acquisition $^{17}$. However, while the benefits of ICTs adoption and utilization are not in doubt, it is also true that the adoption, rapid diffusion and utilization of ICTs in teaching and learning have developed number of demands and challenges such as technostress and job burnout into workplace. Technostress is described as one's inability to cope or deal with ICTs in a healthy manner ${ }^{2}$. Addressing technostress is very important for organizations, because it can impact individuals' health and productivity ${ }^{6,18}$. Previous researches in technostress have mostly focused on the consequences of technostress on performance and satisfaction ${ }^{6,19}$. Past literatures found that the rise of occupational stress is one of the major challenges of technological revolution in the workplace ${ }^{20,21,22}$. The usage of advanced ICT technologies like computer integrated system, CDROMs and multiple databases, the Internet and World Wide Web have also caused an enormous amount of strain on academicians. Occupational stress has been found to have negative influence on employee satisfaction. It is also found that the higher levels of stress have been associated with lower organisational commitment and satisfaction ${ }^{23,24}$.

There are many studies showing correlation between job satisfaction, job performance, and technostress. Raftar $(1998)^{25}$ found a positive association between technostress and job performance i.e. adopting new technology effectively led to better 
performance and vice versa. Although technologies are now a basic component of academic activities in the form of automation, digital learning ${ }^{26}$, but numerous academicians are suffering from technostress. The utilization of ICT in academic in different forms such as teaching, learning and research etc has caused technostress. These technostress significantly reduced the workers (academicians) over all job satisfaction ${ }^{27}$. Technologies have facilitated the easy work environment for employees in different organization. So, they need to learn about the new ICT skills to adopt the changes. On the other hand, ICT induced technostress among academician. There are multiple issues in learning of these technological innovations such as age, technological competencies, attitude towards the adoption of technology, stress management programs, information overload, job insecurity and appropriateness ${ }^{6,18,27,28,29,30}$. Ragu-Nathan et al. $(2008)^{17}$ found a negative association between technostress and job satisfaction. It means that increase in technostress in their work place decreases the satisfaction significantly. It also means that job satisfaction can be enhanced by efficiently controlling the technostress among workers by the concerned organization. They also indicated that techno-complexity, techno-insecurity, techno-overload, techno-invasion, and techno-uncertainty are negatively correlates with job satisfaction. Sinha ${ }^{26}$ found that employees suffering from technostress have low productivity and job satisfaction. Ayyagari ${ }^{28}$ has also identified a negative correlation between technostress and job satisfaction. He further elaborated that fast changing technology is a strong predictor of job dissatisfaction among employees. Pors $(2003)^{27}$ found a strong correlation between job satisfaction and level of stress due to technology and other demographic characteristics. Many studies indicated that there is a relationship between stress and job satisfaction due to fast changing technological innovations .

In last couple of years India is on the verge of an Internet boom with a projected user base from 330 million in 2014 to 370 million by $2015^{31}$. India will become the second largest in the world and largest in terms of incremental growth by 2015 . The penetration of ICT in Indian education system has largely influenced the teaching pedagogy, research orientation among academician. But large section of academicians is not very ICT savvy. This is the one of the important reason of technostress among academician in India. So, a study is required to measure the adverse effect of technostress among Indian academicians. Unfortunately, best of my knowledge there are no such studies have been conducted so far among Indian academicians. Therefore, based on the above literature review, this research was designed to measure the effect of technostress on job satisfaction among Indian academicians. The next section, discusses the proposed model used for this study.

\section{Theoretical Framework and Hypothesis}

There are mainly five different types of technostress creators (Techno-overload, Techno-invasion, Technocomplexity, Techno-insecurity, and Techno-uncertainty) have been identified in literature ${ }^{6}$. In this model (shown in fig. 1) different factors of technostress were treated as independent variable while job satisfaction was treated as dependent variable. Based on this model, the following hypotheses were formulated:

H1: There is a statistically significant relationship between techno-overload and job satisfaction among university teachers

H2: There is a statistically significant relationship between techno-invasion and job satisfaction among university teachers

H3: There is a statistically significant relationship between techno-complexity and job satisfaction among university teachers.

H4: There is a statistically significant relationship between techno-insecurity and job satisfaction among university teachers.

H5: There is a statistically significant relationship between techno-uncertainty and job satisfaction among university teachers.

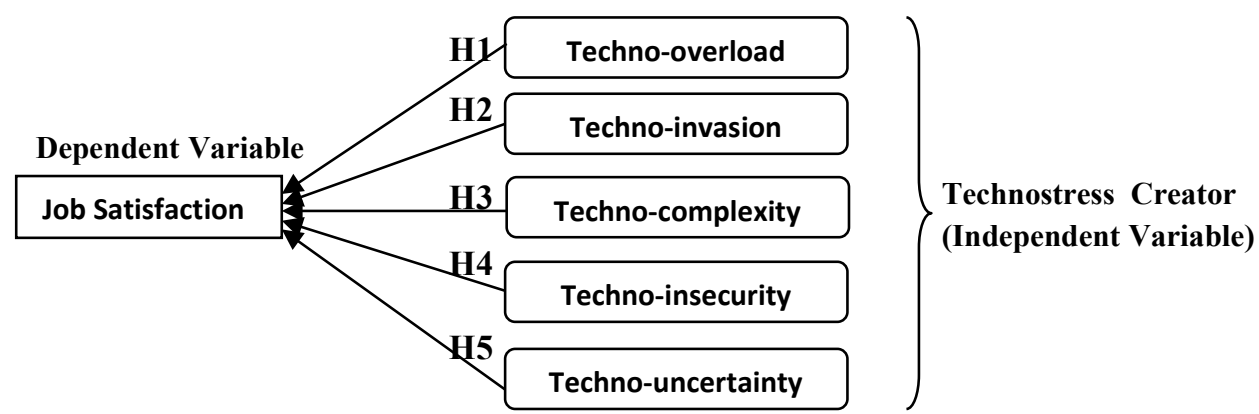

Fig. 1. Proposed relationship Diagram 
Table 1. Demographic Information of sample

\begin{tabular}{|c|c|c|c|}
\hline Attribute & Characteristics & $\mathbf{n}$ & $\mathbf{( \% )}$ \\
\hline \multirow{2}{*}{ Gender } & Male & 117 & 58 \\
\cline { 2 - 4 } & Female & 99 & 42 \\
\hline \multirow{2}{*}{ Age } & Below 35 & 103 & 46 \\
\cline { 2 - 4 } & Above 35 & 113 & 54 \\
\hline \multirow{2}{*}{ Marital Status } & Bachelor & 85 & 39 \\
\cline { 2 - 4 } & Married & 131 & 61 \\
\hline \multirow{2}{*}{$\begin{array}{c}\text { Duration of } \\
\text { Service }\end{array}$} & $\leq 5 y r s$ & 56 & 26 \\
\cline { 2 - 4 } & $6-10 y r s$ & 45 & 21 \\
\cline { 2 - 4 } & $11-15$ & 54 & 25 \\
\cline { 2 - 4 } & $16-20$ & 33 & 15 \\
\cline { 2 - 4 } & $\geq 21$ & 28 & 13 \\
\hline
\end{tabular}

\section{Methodology}

\subsection{Population and Sampling Techniques}

A survey method was employed to collect data regarding demographic profile, technostress and job satisfaction levels of teachers of various universities and colleges in India. The target sample size of 350(N) was considered for this empirical investigation. Out of
350 questionnaires distributed through e-mails and social forum, only 226 questionnaires were returned. After, initial data screening, only 216 questionnaires were found suitable as useable after discarding missing, erroneous or incomplete data for further statistical analyses. The survey response rate was calculated as $62 \%$, which confirms the standards of social science research ${ }^{32}$. "Table 1 " shows the demographic description of the sample.

\subsection{Measuring Instrument}

The five dimensions (total 20 items) of technostress ${ }^{6}$ and overall job satisfaction (total 3 items) along with demographics scales were used for this study. Responses on all items were gathered through 5-point Likert scale anchored as $1=$ Strongly Disagree, $2=$ Disagree, 3= Neutral, 4= Agree, 5= Strongly Agree.

\subsection{Data Analysis}

The factor analysis with principal component analysis (orthogonal varimax) procedure was applied in the collected data in order to verify the construct validity of the factors.

Table 2. Result of Factor Analysis

\begin{tabular}{|c|c|c|c|c|c|c|}
\hline & $\begin{array}{l}\text { Techno- } \\
\text { overload } \\
\text { (OV) }\end{array}$ & $\begin{array}{l}\text { Techno- } \\
\text { invasion } \\
\text { (IN) }\end{array}$ & $\begin{array}{l}\text { Techno- } \\
\text { complexity } \\
\text { (CO) }\end{array}$ & $\begin{array}{l}\text { Techno- } \\
\text { insecurity } \\
\text { (INS) }\end{array}$ & $\begin{array}{l}\text { Techno- } \\
\text { uncertainty } \\
\text { (UN) }\end{array}$ & $\begin{array}{l}\text { Job } \\
\text { Satisfaction } \\
\text { (JS) }\end{array}$ \\
\hline OV1 & 0.81 & & & & & \\
\hline OV2 & 0.79 & & & & & \\
\hline OV3 & 0.83 & & & & & \\
\hline OV4 & 0.64 & & & & & \\
\hline OV5 & 0.66 & & & & & \\
\hline IN1 & & 0.65 & & & & \\
\hline IN2 & & 0.78 & & & & \\
\hline IN3 & & 0.67 & & & & \\
\hline IN4 & & 0.66 & & & & \\
\hline CO1 & & & 0.71 & & & \\
\hline $\mathrm{CO2}$ & & & 0.78 & & & \\
\hline $\mathrm{CO3}$ & & & 0.68 & & & \\
\hline $\mathrm{CO4}$ & & & 0.72 & & & \\
\hline CO5 & & & 0.64 & & & \\
\hline INS1 & & & & 0.61 & & \\
\hline INS2 & & & & 0.77 & & \\
\hline INS3 & & & & 0.62 & & \\
\hline INS4 & & & & 0.72 & & \\
\hline INS5 & & & & 0.58 & & \\
\hline UN1 & & & & & 0.61 & \\
\hline UN2 & & & & & 0.84 & \\
\hline UN3 & & & & & $\begin{array}{l}0.78 \\
0.78\end{array}$ & \\
\hline UN4 & & & & & 0.59 & \\
\hline JS1 & & & & & & 0.67 \\
\hline JS2 & & & & & & 0.82 \\
\hline JS3 & & & & & & 0.77 \\
\hline
\end{tabular}


Table 3. Result of Goodness of Fit

\begin{tabular}{|l|l|}
\hline Model Indices & Values \\
\hline Chi-square/degrees of freedom & 1.4 \\
\hline Goodness-of-fit index (GFI) & 0.91 \\
\hline Adjusted goodness-of-fit index (AGFI) & 0.82 \\
\hline Normed fit index (NFI) & 0.93 \\
\hline Tucker-Lewis index (TLI) & 0.93 \\
\hline Comparative fit index (CFI) & 0.94 \\
\hline $\begin{array}{l}\text { Root mean square error of approximation } \\
\text { (RMSEA) }\end{array}$ & 0.05 \\
\hline
\end{tabular}

\subsubsection{Factor Analysis}

The first task of this analysis was to check the factor structures of the constructs and confirm them with the original studies. So, the exploratory factor analysis was conducted using collected data. It yields six factors as shown in "Table 2". All the factor loadings (Table 2) were at an acceptable level, and there were no crossloadings above 0.4 .

In addition, the procedure suggested by Harman's single-factor test for common method bias was adopted and found that no single factor explains the majority of the variance in the variables, thereby providing evidence against single-respondent bias ${ }^{33}$.

Even though exploratory factor analysis provided a measure of convergent and discriminant validity of constructs, it does not test for possible error correlations among items. Therefore a measurement models using confirmatory factor analysis for each first-order construct was developed using structural equation modeling ( AMOS). Then a first-order correlated model on these ' 6 ' factors was run to identify significant correlations among their error terms. The model fit indices were shown in "Table-3."
But based on the past literature, the recommended values for chi-square/degrees of freedom should lies between ' 1 ' and ' 5 , 33 . According to Hair ${ }^{34}$, GFI $>0.85$ and AGFI $>0.8$ represent an acceptable fit. Recommended values for NFI and TLI are $>0.90$, and for $\mathrm{CFI}>0.90^{34}$. RMSEA values less than 0.1 signify a good fit ${ }^{33,34}$. So, the values found from "Table 3 " for different model indices satisfy the acceptable levels mentioned above. This implies that there are no significant correlations between the error terms. Therefore, it confirms the convergent and discriminate validity among the factors.

After the first order model, the six factors were further analyzed at the second order level. The analysis was carried out to achieve a valid model fit for the data obtained as well as theoretical supports behind the developed model. The second-order constructs for the six factors were verified by calculating the ratio of the chi-square values of the first-order and second-order models ${ }^{36}$. It basically indicates the percentage of variance explained by the second-order model compared to the first-order correlated model. The tcoefficient value in this case was found 0.94 . According to Marsh ${ }^{36}$, the recommended value for this coefficient is 0.8 . So, the second-order coefficients in the measurement model are found to be significant at the 0.05 level. This indicates the presence of the second-order construct. Therefore after the tests, technostress and job satisfaction were found as second order construct. Technostress comprised of five firstorder sub-constructs (techno-overload, techno-invasion, techno-complexity, techno-insecurity, and technouncertainty), where as Job satisfaction had only one sub- component.

Table 4. Result of descriptive statistic

\begin{tabular}{|l|l|l|l|}
\hline & Mean & $\begin{array}{l}\text { Standard } \\
\text { Deviation }\end{array}$ & $\begin{array}{l}\text { Cronbach's } \\
\text { alpha }\end{array}$ \\
\hline Techno-overload (OV) & 3.01 & 0.72 & 0.83 \\
\hline Techno-invasion (IN) & 2.12 & 0.81 & 0.87 \\
\hline Techno-complexity (CO) & 2.89 & 0.67 & 0.82 \\
\hline Techno-insecurity (INS) & 2.23 & 0.78 & 0.78 \\
\hline Techno-uncertainty (UN) & 3.26 & 0.57 & 0.83 \\
\hline Job Satisfaction (JS) & 2.07 & 0.89 & 0.74 \\
\hline
\end{tabular}

Table 5. Correlations between Technostress Creators and Job Satisfaction

\begin{tabular}{|l|l|l|l|l|l|l|}
\hline & OV & IN & CO & INS & UN & JS \\
\hline Techno-overload (OV) & 1 & $-0.4^{*}$ & 0.19 & 0.36 & $0.23^{*}$ & $-0.71^{*}$ \\
\hline Techno-invasion (IN) & & 1 & 0.51 & 0.47 & -0.13 & $-0.83^{*}$ \\
\hline Techno-complexity (CO) & & & 1 & $0.48^{*}$ & 0.14 & $-0.82^{*}$ \\
\hline Techno-insecurity (INS) & & & & 1 & 0.02 & $-0.79^{*}$ \\
\hline Techno-uncertainty (UN) & & & & & 1 & $-0.77^{*}$ \\
\hline
\end{tabular}

*. Correlation is significant at the 0.01 level (2-tailed). 
Table 6. Result of Hypotheses Testing

\begin{tabular}{|l|l|l|l|l|l|}
\hline Path & $\begin{array}{l}\text { Unstd. } \\
\text { Factor } \\
\text { Load. }\end{array}$ & $\begin{array}{l}\text { Std. } \\
\text { Factor } \\
\text { Load. }\end{array}$ & t-value & p & Result \\
\hline OV $\rightarrow$ JS & -0.23 & -0.16 & -2.34 & 0.00 & Accept \\
\hline IN $\rightarrow$ JS & -0.26 & -0.18 & -1.23 & 0.01 & Accept \\
\hline CO $\rightarrow$ JS & -0.31 & -0.21 & -2.14 & 0.00 & Accept \\
\hline INS $\rightarrow$ JS & -0.29 & -0.21 & -1.89 & 0.03 & Accept \\
\hline UN $\rightarrow$ JS & -0.25 & -0.19 & -2.12 & 0.01 & Accept \\
\hline
\end{tabular}

The factor reliabilities (Cronbach's alpha), means, and standard deviations in the context of university teachers in India were shown in "Table 4". The Cronbach's alpha was used as reliability score of the scales. Nunnally ${ }^{35}$ recommended at least 0.70 alpha coefficients for social sciences as acceptable. The internal reliabilities of overall scale were calculated and found high internal consistency and reliability for all variables (Table 4).

The results in table- 5 showed no correlation greater than 0.7 between technostress creators. So, it can be asserted that there is no problem in multicollinearity in the collected data. But strong correlations found between technostress creators and job satisfaction.

\subsubsection{Path Analysis and Hypothesis Testing}

The Structural Equation Model (SEM) was used to test the proposed hypothesis. The results of the structural equation model in form of standardized factor loading, standard errors, and t-value were shown in table 6. It was also found that most of the standard errors were less than 0.1. Therefore, the results of SEM were found reliable.

It was found that technostress creator (OV) signifycantly affect the job satisfaction $(\mathrm{p}=0.00<0.05, \mathrm{t}=-$ 2.34).Therefore hypothesis (H1) was accepted. The negative $t$-value (-2.34) implied that the increase in OV reduce job satisfaction. Similarly, all the technostress creators (IN, CO, INS, UN) significantly and negatively affect technostress. That increase of any of the technostress creator decreases job satisfaction among Indian academician. Therefore all the hypothesis (H1, $\mathrm{H} 2, \mathrm{H} 3, \mathrm{H} 4, \mathrm{H} 5$ ) were accepted.

\section{Discussion}

The goal of this research was to extend the technostress literature by associating job satisfaction with five important technostress creators in Indian condition. This research was used personal environmental framework to explain why the misfit between individual abilities and computing enabled environment demands, lead to technostress. The results of this research showed a direct impact of technostress on job satisfaction. Similar results have been reported by Ragu-Nathan et al. ${ }^{17}$ in their research. They found that academicians, who attempt to cope with technostress are likely to have less negative impact on their jobs. As far as technostress is concerned, recent studies have investigated the influence of technostress on job satisfaction 17,37,38,39. Weil and $\operatorname{Rosen}^{20}$ and Brod $^{2}$ reported that technostress is responsible for information fatigue, loss of motivation, and dissatisfaction at work. Similarly, Corbett et al. $(1989)^{40}$ found work changes resulting from the use of computer-base technologies were associated with decreased job satisfaction. All the past findings were similar to findings of this research. Overall the summary of this research found that the existence of technostress creators lead to decline in job satisfaction. This fact has been supported by many researchers ${ }^{19,39}$. Therefore from the above discussion, it was found that user experience the "technostress" due to information overload, ICT invasion of personal life, complexity of IS, and a sense of insecurity due to rapid change in ICT. Technostress may significantly reduce job satisfaction, commitment, innovation, and productivity. A consequence of technostress leads to job dissatisfaction, which promotes low productivity and high employee turnover in academic organizations.

\section{Conclusion \& Recommendations}

This research was conducted to study the impact of technostress and job satisfaction among academicians in India. The results showed a negative impact of technostress on job satisfaction among Indian academicians. It is hoped that the results provided in this research provide an avenue for academic institutions to address technostress. Given the fast changing ICT trend and an increasingly faster-paced stressful work environment, it seems reasonable to 
develop effective training and wellness programs to decrease academicians' stress levels and to enhance their sense of technological mastery and personal value in Indian condition. Finally, as a result of this study, the following recommendations may be made in accordance with previous studies ${ }^{41,42}$.

- Establishment of time management and healthy environment to ensure the acceptance and acknowledgement of technology as a vital aspect of academic life.

- Ensuring the procurement of relevant technologies by the academic institutions and providing the opportunity for personal development to academicians regarding the use of these technologies through seminars, training, courses etc.

- Creating the awareness of new technological developments from time to time.

\section{References}

1. Vieitez, J. C., Carcia, A. D. L. T., \& Rodriguez, M. T. V., Perception of job security in a process of technological change: Its influence on psychological well-being. Behaviour \& Information Technolog, 20 (3) ( 2001) 213223.

2. Brod, C., Technostress: The human cost of the computer revolution. (Reading: Addison-Wesley, 1984).

3. Davis-Millis, N., Technostress and the organization: A manager's guide to survival in the information age. In the 67th Annual Meeting of the Music Library Association, 14 February,1998, Boston, Massachusetts. Retrieved from http://web.mit.edu/ninadm/www/mla.htm

4. Clark, K., \& Kalin, S., Technostressed out? How to cope in the digital age. Library Journal, (1996) 30-32.

5. Francis, Olalude Oluwole, Work Values, Achievement Motivation and Technostress as Determinants of Job Burnout among Library Personnel in Automated Federal University Libraries in Nigeria. Library Philosophy and Practice (e-journal). (2013) Paper 919. http://digitalcommons.unl.edu/libphilprac/919

6. Tarafdar, M. T. Q., Ragu-Nathan, B.S., \& Ragu-Nathan, T.S., The impact of technostress on role stress and productivity, Journal of Information Management Systems 24(1) (2007) 301-328.

7. Somvir, S. K., Job satisfaction among library professionals in Haryana state. International Journal of scientific and research Publications, 2(5) (2012) 1- 5.

8. Aydogdu, S. \& Asikgil, B., An empirical study of relationship among job satisfaction, organizational commitment, and turnover intention. International Review of Management and Marketing 1(3) (2011) 4253.
9. Hart, G., Job satisfaction in South African academic library in transition. Journal of Academic Librarianship 36(1) (2010) 35- 62.

10. Leysen, J.M. \& Boydston, J. M.K., Job satisfaction among academic cataloger. Collection and Technical Services Publications 5 (2009) 273-297.

11. Spector, P.E., Measurement of human service staff satisfaction: Development of the job satisfaction survey. American Journal of Community Psychology 13(6) (1985) 693-713.

12. Ayyagari, R., Grover, V., and Purvis, R.L., Technostress: Technology a ntecedents and implications, MIS Quarterly, 35( 4) (2011) 831-858

13. Tu, Q., Wang, K., and Shu, Q., Computer-related technostress in China, Communications of the ACM 48(4) (2005) 77-81.

14. Grise, M-L. and Gallupe, R.B., Information overload: Addressing the productivity paradox in face-to-face meetings, Journal of Management Information Systems 16( 3) (1999) 157-185.

15. Agbonlahor, R. O., Motivation for use of information technology by university faculty: a developing country perspective, Information Development 22(4) (2006) 263 $-277$.

16. Ayyagari, R., Grover, V., and Purvis, R.L., Technostress: Technology antecedents and implications, MIS Quarterly 35(4) (2011) 831-858.

17. Ragu-Nathan, T. S., Tarafdar, M., Ragu-Nathan, B. S., and $\mathrm{Tu}, \mathrm{Q}$., The consequences of technostress for end users in organizations: Conceptual development and empirical validation, Information Systems Research 19 (4) (2008) 417-433.

18. Laff, M., Got stress? $T+D \mathbf{6 0}$ (7) (2006) 31-36

19. Rosen, L. D., \& Weil, M. M., Results of our 49-month study of business attitudes show clerical/support staff, managers and executives using more technology at work and at home and becoming more hesitant toward new technology. Byte Back, LLC and Human-Ware, LLC (2000) 1-16. Retrieved from http://www.technostress.com/busstudy2000.htm

20. Lopopolo, R. B., The relationship of role-related variables of job satisfaction and commitment to the organization in a restructured hospital environment. Physical Therapy 82 (10) (2002) 984-999.

21. Ahmad, U. N., Amin, S. M., \& Ismail, W. K. W., The impact of technostress on organizational commitment among Malaysian academic librarians. Singapore Journal of Library \& Information Science 38 (2009) 103-123.

22. Ameen, K., Perception and self-assessment of university librarians regarding collection management $(\mathrm{CM})$ : A case of Pakistan. Collection Building 24(4) (2008) 167173 .

23. Mahmood, K., LIS curriculum review using focus group interviews of employers (2012). Retrieved December 10,2014 from http://digitalcommons.unl.edu/cgi/ viewcontent.cgi?article $=1830 \&$ context $=$ libphilprac

24. Ullah, M., Professional activities, needed competencies, and training needs of medical librarians in Pakistan Education for Information 28(2-4) (2010) 115-123. 
25. Raftar, M. Technostress takes toll on internet users. Akron Beacon Journal D8 (1998)

26. Sinha, C. Factors affecting quality of work life: Empirical evidence from Indian organizations. Australian Journal of Business and Management Research 1(11) (2012) 3-40

27. Pors, N. O., Job satisfaction among library managers: a cross-cultural study of stress, freedom and job conditions. New Library World 104(11/12) (2003) 464-473.

28. Ayyagari R, Impact of Information overload and taskTechnology fit on Technostress, In Proceedings of the Southern Association for Information Systems Conferenc (Atlanta, GA, USA March 23rd-24 ${ }^{\text {th }}, 2012$ ), pp 18-22

29. Uma, Sekaran, Research Methods for Business: A Skillbuilding Approach (Third Ed. New York: John Wiley \& Sons, Inc, 2000)

30. Testa, M. R., Organizational commitment, job satisfaction and efforts in the service environment. Journal of Psychology 135(2) 2001) 226-237

31. McKinsey \& Company, Inc, Online and upcoming: The Internet's impact on India, (2012) http:// www.mckinsey.com/.../india/.../online and upcoming $\mathrm{t}$ he_internets_impact_on_india.ashx

32. Sekaran, U., Research methods for business. A skill building approach, ((3rd ed.) New York: Wiley, 2000)

33. Salisbury, W.D.; Chin, W.W.; Gopal, A.; and Newsted, P.R, Research report: Better theory through measurement-Developing a scale to capture consensus on appropriation. Information Systems Research 13(1) (2002) 91-103.

34. Hair, J.F.; Anderson, R.E.; Tatham, R.L.; and Black, W., Multivariate Data Analysis with Readings (Upper Saddle River, NJ: Prentice Hall, 1998).
35. Nunnally, J.C. Psychometric Theory ( New York: McGraw-Hill, 1978).

36. Marsh, H.W., and Hocevar, D, Application of confirmatory factor analysis to the study of self-concept: First- and higher-order factor models and their invariance across groups. Psychological Bulletin 97( 3) (1985) 562-582.

37. Asad Khan, Hamid Rehman, Shafiq-ur-Rehman, An Empirical Analysis of Correlation Between Technostress and Job Satisfaction: A Case of KPK, Pakistan, Pakistan Journal of Library and Information Science 13 (2013) 9-15.

38. Rajesh Kumar, Roshan Lal, Yashu Bansal, Saran.K.Sharma, Technostress in relation to Job satisfaction organisational Commitment among IT Professional, International Journal of Scientific and Research Publications 3(12) (2013) 1-3.

39. Agbu Jane-Frances O. and Olubiyi Kayode Simeon, (2011), Technostress in the age of information communication technology: A case study of distance education, Educational Research 2(11) (2011) 16541660 .

40. Corbett, J. M., Martin, R., Wall, T. D., \& Clegg, C. W., Technological coupling as a predictornote of intrinsic job satisfaction: A replication study, Journal of Organizational Behavior 10(1) (1989) 91-95.

41. Wang, K. Tu, Q. \& Shu,Q., Technostress under Different Organizational Environments: An Empirical Investigation", Computers in Human Behavior 24 (2008) 3002-3013.

42. Ahmet Naci Çoklar, Yusuf Levent Sahin, Technostress Levels of Social Network Users Based on ICTs in Turkey, European Journal of Social Sciences 23(2) (2011) 171-182. 